\title{
Determinants of the marginal willingness to pay for improved domestic water and irrigation in partially electrified Rwandan villages
}

\author{
Simon Meunier ${ }^{1 *}$, Dale T. Manning ${ }^{2}$, Loïc Quéval ${ }^{1}$, Judith A. Cherni ${ }^{3}$, Philippe Dessante ${ }^{1}$, \\ Daniel Zimmerle ${ }^{4}$ \\ ${ }^{I}$ GeePs | Group of electrical engineering - Paris, CNRS, CentraleSupélec, University Paris-Sud, University \\ Paris-Saclay, Sorbonne University, Gif-sur-Yvette, France \\ ${ }^{2}$ Department of Agricultural and Resource Economics, Colorado State University, Fort Collins, USA \\ ${ }^{3}$ Centre for Environmental Policy, Imperial College London, London, UK \\ ${ }^{4}$ Energy Institute, Colorado State University, Fort Collins, USA
}

*Correspondence: Simon Meunier, Group of electrical engineering - Paris, 11 Rue Joliot Curie, 91192 Gif-sur-

Yvette, France. E-mail: simon.meunier@centralesupelec.fr

\begin{abstract}
Access to water for domestic and irrigation uses remains limited across Sub-Saharan Africa, particularly in rural areas. While the technical feasibility of implementing innovative technologies to improve water supply has been often evaluated, less is known about the drivers that motivate users to pay for obtaining the inherent benefits of improved water supply. In this article, the determinants of the marginal willingness to pay (mWTP) for improved domestic and irrigation water are investigated. For this purpose, a contingent valuation study is performed in rural Rwanda. This study uses survey data from 316 households situated in 8 villages, in which $\sim 20 \%$ of the households receive electricity thanks to microgrids powered by solar energy. It is found that the mWTP for improved domestic water supply is influenced by the proportion of children in the household, business ownership, and satisfaction with water quantity and quality. The mWTP for irrigation is determined by respondent education, business ownership and crop area planted. This paper contributes to the literature by allowing a comparison of the determinants of the mWTP for improved domestic water supply to the determinants of the mWTP for irrigation. Another contribution is to examine the mWTP for improved water infrastructure in partially electrified villages. Identifying areas with high marginal benefits from water can guide infrastructure investment and electrification efforts while improving well-being and increasing revenues in rural areas.
\end{abstract}

Keywords: Domestic water, Irrigation, Electricity access, Contingent valuation, Willingness to pay, Rwanda

\section{Introduction}

In Sub-Saharan Africa, more than 300 million people use unimproved water sources, notably in rural areas (United Nations [UN] 2015). Correlation and causality between low quality water, which does not meet the international standards for drinking (World Health Organization, 2011), and diseases such as diarrhea, trachoma or malaria have been clearly established (Howard and Bartram 2003). Unimproved water supply is also associated with significant time losses due to long travel times and queuing times at water points (Bartram and Cairncross 2010). In addition to the lack of water for domestic uses, water for irrigation is also scarce in Africa and is concentrated in a few countries (You et al. 2011). Improving supply to domestic water and irrigation is key to foster socio-economic development (Bartram and Cairncross 2010; Yami 2016). Rwanda is a relevant country to study water access challenges because $52 \%$ of the rural population does not have access to basic water services for domestic use (Rwandan Ministry of Infrastructure 2017) and daily domestic water collection time is significant (Ngoga 2015). The Rwandan government has set ambitious objectives for domestic water access, as it aims at providing 'basic water access' to the whole population by 2020 and access to 'safely managed water' by 2030 (Rwandan Ministry of Infrastructure 2017). Regarding irrigation, despite the important water resources in Rwanda, motorized irrigation remains largely unexploited (Ngabonziza and Maimbo 2010). Improving affordable water infrastructure in poor rural areas can also help Rwanda achieve UN sustainable development goal number 6 (UN 2018), which is to increase access to clean water and sanitation.

Researchers, policymakers, and entrepreneurs have been working on technological innovations to improve water supply in rural areas, notably through the use of solar energy (Kaldellis et al. 2009; Campana et al. 2013). For instance, solar pumping systems for domestic water (Meunier et al., 2019) and for irrigation (Campana 
et al., 2013) were modelled, and Kaldellis et al. (2009) modelled a system where solar energy is used both for pumping and for another electrical load such as lighting. Moreover, solar pumping is a productive electricity use that is very often considered by microgrid companies. In Rwanda, increasing the occurrence of motorized irrigation, notably through the installation of diesel pumps, is one of the major objectives of the governmental 'Irrigation Master Plan' presented in 2010 (Ngabonziza and Maimbo 2010). In addition to public efforts, Rwanda also has an active private sector related to water and electricity access. For example, the company Gaia Survey has been working in water resources engineering, the firms Meshpower (Meshpower 2018) and Bbox (Bbox 2018) have been providing electricity access in rural areas, and FuturePump has been installing solar pumps for smallholder irrigation (Davies 2017).

However, the problem of water access cannot be solved solely through improved water supply technologies. Households' willingness to pay (WTP) for the service is also a crucial part of finding a sustainable solution for providing pumped water (World Bank 1993). Understanding the drivers of the WTP for improved domestic and irrigation water can ensure that innovations reach the households and regions where it generates the most value. It is therefore key for the economic and social sustainability of water infrastructure (Manning et al. 2015). In addition, it may help to predict the use of water resources and may therefore orientate strategies to ensure the environmental sustainability of these resources. Therefore, in this paper, we estimate and compare the determinants of the marginal WTP (mWTP) for improved domestic and irrigation water. This comparison is performed through a comprehensive review of the literature and a contingent valuation method (CVM) survey administered in rural villages of central Rwanda.

The main contribution of our study is to compare the determinants of the mWTP for domestic water with the ones for irrigation. Indeed, previous studies focused only on one of these two uses. The comparison is relevant because it allows us to know if policy schemes which target both domestic water and irrigation can be designed. Our approach, therefore, contributes to the understanding of the marginal value of these two types of water uses. Another contribution of our study is that it occurs in villages in which $20 \%$ of the households are electrified, thanks to microgrids powered by solar energy. This makes motorized water pumping a technically feasible option. It also allows the examination of the relationship between microgrid electricity use and the mWTP for improved water infrastructure. Learning about the demand for new electricity uses, such as motorized water pumping, is key to sustainably improving energy access and meeting sustainable development goal number 7 , related to affordable and clean energy (Manning et al. 2015; UN 2018).

The results of this study help governments, private sector providers, and non-governmental organizations (NGOs) to better target communities where water provision has larger benefits, inform them about the value of investing in water supply, and provide guidance on the prioritization of investments (Bennett and Birol 2010; Perez-Pineda and Quintanilla-Armijo 2013). It also has the potential to improve the financial viability of these investments (Whittington et al. 1991).

Section 2 compares the determinants of the WTP for domestic water and irrigation encountered in the literature. Section 3 presents the study site, the data collected, and the model proposed. Section 4 presents the summary statistics for the variables of the model, and the results of the contingent valuation study. Section 5 discusses policy implications of our results.

\section{Literature review: determinants of the willingness to pay for improved domestic water supply and irrigation}

There are two main methods for estimating the WTP for services from public infrastructure: revealed preferences and stated preferences. Revealed preferences use observations of actual behaviour and choices regarding the public infrastructure. Stated preference methods such as the contingent valuation method, use surveybased methods to elicit WTP for hypothetical goods or services. Survey respondents are asked to state the hypothetical use of a good or the price they would be pay for the good or service. In rural areas of developing countries, revealed preference methods are often not applicable because the investments that are being valued are not yet available, and the results obtained in areas where these investments have taken place do not apply to the targeted rural areas (Manning and Loomis 2016). Therefore, despite their limitations (Hausman 2012), stated preferences methods provide a useful way to value investments in these unserved regions (Manning and Loomis 2016). Several types of stated preference methods have been used to study the value of investments in developing countries, including open ended questions (Al-Assaf 2015), payments cards (Popoola and Ajewole 2010), singlebounded (Alhassan and Mohammed 2013) and double-bounded (Bhattarai 2015) dichotomous choice, choice 
experiments (Kaffashi et al. 2013), and bidding games (Ezebilo et al. 2010).

Here, we review the articles that have tested the correlation between a set of variables and the WTP for either domestic water or irrigation in poor areas of developing countries. It is important to notice that, in these articles, willingness to pay (WTP) is used as a generic term for the propensity to pay. In many cases, these articles actually evaluate the marginal willingness to pay (mWTP), i.e., the maximum price a respondent would pay per unit of water, as in (Calkins et al. 2002) and (Harun et al. 2015), or the amount of money that respondents are prepared to pay for access to a given service, independent of the quantity of water consumed, as in (Perez-Pineda and Quintanilla-Armijo 2013) and (Zakaria et al. 2013). This can be explained by the fact that reliably evaluating the intended water quantity consumed may not be possible, because respondents have not experienced water use with the improved water supply infrastructure proposed. In this article, we also refer to the WTP as a generic term representing the propensity to pay and to the mWTP as the maximum price a respondent would pay per unit of water they would purchase.

While previous studies focus on either domestic water or irrigation, this review aims at comparing the drivers of the WTP for both uses. The results are summarized in Table 1. The WTP for improved domestic water supply and irrigation are separated into two different columns. For each of the reviewed studies, we specify which variables correlate positively, negatively, or do no correlate with the WTP. The variables encountered in the literature are grouped into 3 different categories: demographic, economic, and water access. The results of our contingent valuation study, which are detailed in section 4 , are included in Table 1 as reference "M", to ease comparison to the literature.

The variables that are too study-specific or not sufficiently defined in the articles are not reported. Moreover, we exclude price because we are interested in variables that shift the demand curve across households. When the correlation of a variable with the WTP is not robust to model specifications, it is indicated that there is no correlation. The review on the WTP for domestic water considers access to hand pumps, motorized pumps, and piped water. Indeed, the WTP determinants for these three levels of service are expected to be similar. For irrigation, only studies on small-scale irrigation projects are taken into account.

In a limited number of cases in Table 1, a reference is cited several times for the same variable and WTP category (domestic water or irrigation). For instance (Arouna and Dabbert 2012) is cited twice for the variable "education" and the category "domestic water", as both positively and negatively correlated. In some cases, as in (Arouna and Dabbert 2012), this is because multiple variables (with different signs of the marginal effects) fall within a given variable category of Table 1. In other cases, a reference may combine several studies which find different results. For instance, some references study the WTP for both improved water quantity and quality (Farolfi et al. 2007), and others examine WTP for different levels of improved water supply (Altaf et al. 1992).

A first observation that can be made from Table 1 is that results vary very significantly across studies. A deeper analysis reveals that WTP determinants are very location dependent. In the following paragraphs, the variables which emerge as having a clear influence on the WTP are discussed. It is important to highlight that variables of the table that are not discussed may still influence the WTP in some cases.

Regarding demographic variables, education has a clear and positive impact on the WTP for both domestic water and irrigation. Indeed, people with higher education may be better placed to capitalize on the benefits of improved water supply. Gender also influences the WTP for domestic water. Women are more willing to pay for improved domestic water supply than men, which seems logical as women are most often the household members responsible for water collection in Sub-Saharan Africa (Graham et al. 2016). In addition, we observe that household size seems to increase the WTP for domestic water, which may be due to the fact that water collection for large families is very physically demanding. It also appears that age is negatively correlated with the WTP for domestic water, which might be due to inertia or to the fact that older respondents have a shorter planning horizon. Another explanation may be that older people may not expend as much effort to acquire water, as they may be assisted by neighbours and family for water collection. On the other hand, age is positively correlated with the WTP for irrigation. This could be partly driven by greater experience with drought among older farmers.

The most consistent economic determinant of the WTP for both domestic water and irrigation is wealth, which is consistent with water as a normal good in consumer theory. Crop area planted is positively correlated with the WTP for irrigation. This may occur when irrigated production exhibits economies of scale. 
Table 1 - Determinants of the WTP for improved domestic water supply and irrigation encountered in the literature

\begin{tabular}{|c|c|c|c|c|c|c|}
\hline \multirow[t]{3}{*}{ Variable } & \multicolumn{3}{|c|}{ WTP for domestic water } & \multicolumn{3}{|c|}{ WTP for irrigation } \\
\hline & \multicolumn{6}{|c|}{ Estimated Correlation } \\
\hline & Positive & None & Negative & Positive & None & Negative \\
\hline \multicolumn{7}{|l|}{ Demographic } \\
\hline Education & $\begin{array}{c}123 \\
45 \\
\end{array}$ & $\begin{array}{c}467 \\
8910 \\
\end{array}$ & 3 & $\begin{array}{c}161718 \\
19 \mathrm{M} \\
\end{array}$ & 202122 & 22 \\
\hline Marital status (1 if married) & & 6 & & & 21 & \\
\hline Gender ( 1 if male) & & $\begin{array}{l}1210 \\
1112 \\
\end{array}$ & $\begin{array}{c}1410 \\
13\end{array}$ & & $\begin{array}{c}161920 \\
21\end{array}$ & \\
\hline Age & $313 \mathbf{M}$ & $\begin{array}{c}6810 \\
12 \\
\end{array}$ & $\begin{array}{l}2410 \\
1415 \\
\end{array}$ & 182122 & 162022 & 19 \\
\hline Household size & $\begin{array}{c}4910 \\
15\end{array}$ & $\begin{aligned} 386 \\
91011\end{aligned}$ & 212 & 18 & $\begin{array}{c}161720 \\
21\end{array}$ & \\
\hline $\begin{array}{l}\text { Awareness of water borne diseases } \\
\text { (1 if aware) }\end{array}$ & 13 & $\begin{array}{l}258 \\
911 \\
\end{array}$ & & & & \\
\hline \multicolumn{7}{|l|}{ Economic } \\
\hline Wealth/income/expenditure & $\begin{array}{llll}1 & 2 & 3 & 4 \\
6 & 8 & 11 \\
13 & 15\end{array}$ & $\begin{aligned} 456 \\
91012\end{aligned}$ & 7910 & 1819 & 16 & \\
\hline $\begin{array}{l}\text { Distance from the household to the } \\
\text { nearest market }\end{array}$ & & & & & 16 & 17 \\
\hline Property owned (1 if owned) & & 4 & & & & \\
\hline $\begin{array}{l}\text { Involvement in off farm income } \\
\text { activity ( } 1 \text { if involved) }\end{array}$ & $7 \mathbf{M}$ & 4 & & $\mathbf{M}$ & 1722 & \\
\hline Access to credit ( 1 if access) & & & & 17 & 16 & \\
\hline Income from irrigated farm & & & & 16 & & \\
\hline $\begin{array}{l}\text { Insecurity of land tenure } \\
\text { (1 if insecure) }\end{array}$ & 15 & & & & & \\
\hline Land owned (1 if owned) & & & & 18 & & 20 \\
\hline Lease price of the farmland & & & & & & 20 \\
\hline Area planted & & & & $1719 \mathrm{M}$ & 22 & \\
\hline \multicolumn{7}{|l|}{ Water access } \\
\hline Expenditure for current water access & 7 & 5 & & & & 18 \\
\hline Time/Distance to the current source & $\begin{array}{l}1413 \\
1415 \\
\end{array}$ & 8 & & & 17 & 16 \\
\hline $\begin{array}{l}\text { Satisfaction with current water } \\
\text { supply (in terms of quantity and } \\
\text { quality) ( } 1 \text { if satisfied) }\end{array}$ & & $\begin{array}{l}458 \\
1112\end{array}$ & $\begin{array}{l}124 \\
9 \mathbf{M}\end{array}$ & & 21 & \\
\hline $\begin{array}{l}\text { Awareness/participation in water } \\
\text { supply projects ( } 1 \text { if aware) }\end{array}$ & & 41011 & 10 & 16 & & \\
\hline $\begin{array}{l}\text { Satisfaction with previous water } \\
\text { improvement projects ( } 1 \text { if satisfied) }\end{array}$ & 10 & & & & & \\
\hline Quantity of water consumed & 413 & & 1213 & & & \\
\hline $\begin{array}{l}\text { Respondent considers that water } \\
\text { should be provided for free by the } \\
\text { state ( } 1 \text { if yes) }\end{array}$ & & 4 & & & & \\
\hline Queuing time/Time spent pumping & 9 & 3 & & & & \\
\hline $\begin{array}{l}\text { Awareness of best agricultural } \\
\text { practices ( } 1 \text { if aware) }\end{array}$ & & & & 17 & 1617 & 16 \\
\hline $\begin{array}{l}\text { Irrigation experience } \\
\text { (1 if experienced })\end{array}$ & & & & 1719 & & \\
\hline
\end{tabular}

For each variable, references that find that it does not correlate with the WTP (p-value $>0.1$ ) are below "None", the ones that find that it correlates positively are below "Positive" and the ones that find that it correlates negatively are below "Negative". References on domestic water: 1 (Whittington et al. 1990); 2 (Wondimu and Bekele 2011); 3 (Arouna and Dabbert 2012); 4 (Altaf et al. 1992); 5 (Rahman et al. 2017); 6 (Adenike and Titus 2009); 7 (Whittington et al. 1991); 8 (Boadu 1992); 9

(Akram and Olmstead 2011); 10 (Kaliba et al. 2003); 11 (Perez-Pineda and Quintanilla-Armijo 2013); 12 (Fujita et al. 2005); 13 (Farolfi et al. 2007); 14 (Wright et al. 2014); 15 (Calkins et al. 2002).

References on irrigation: 16 (Kiprop et al. 2017); 17 (Angella et al. 2014); 18 (Akter 2006); 19 (Mezgebo et al. 2013 ); 20

(Alhassan et al. 2013); 21 (Zakaria et al. 2013); 22 (Harun et al. 2015).

Results of this study: "M". 
For variables related to water access, the WTP for improved domestic water supply is mostly driven by time/distance to the current water source and the dissatisfaction, in terms of quantity and quality, with the current water supply. Indeed, the distance to the water point and the time allocated to collect water are some of the major issues related to water access in the literature (Bartram and Cairncross 2010; World Health Organization and United Nations Children's Fund 2010). Moreover, some options for providing improved water supply, such as piped water, are very attractive to people who live far away from the water source for it enables them to save a large amount of time. For irrigation, a key determinant is irrigation experience: people who have tried irrigation are more likely to invest in it. Indeed, they may be more acquainted with the advantages of irrigation and may have the knowledge to put additional water to beneficial use.

In addition to providing a summary of WTP studies for improving water infrastructure in developing countries, this literature review allows us to identify the variables that are likely to influence the mWTP for domestic water and irrigation, separately. These variables have been selected for our contingent valuation study in Rwanda (see section 3.3). This literature review also highlights that previous articles did not study the correlation between electricity access and the WTP for domestic water or irrigation. In order to investigate a possible link, the electricity access variable has been included in our contingent valuation study.

\section{Research methods}

\subsection{Study site}

The contingent valuation study is performed in 8 remote rural villages in the districts of Bugesera, and Ngoma in Rwanda (Note 1). The surveyed villages are located in the area specified by the black rectangle in Figure 1. In aggregate, there are 1594 households and approximately 7000 inhabitants in the 8 villages. Approximately $80 \%$ of the inhabitants work in agriculture and the average household monthly income is 50 USD. Houses do not have access to piped water and have to collect domestic water manually at surface sources or wells. Moreover, very few farmers irrigate their fields.

Households are not connected to the Rwandan national electricity grid and the majority of the electrified households of the villages are customers of a single microgrid company. In total, $20 \%$ of the 1594 households are electricity customers and the villages are therefore partially electrified. Microgrids are powered by photovoltaic (solar) energy with battery storage. Customers are served with low-voltage DC electricity suitable for lighting, mobile phone charging, and small appliances such as radios or televisions. Such microgrids are capable of supporting productive uses of electricity, including motorized water pumping. The surveyed villages are representative of other poor and partially electrified villages in Rwanda.

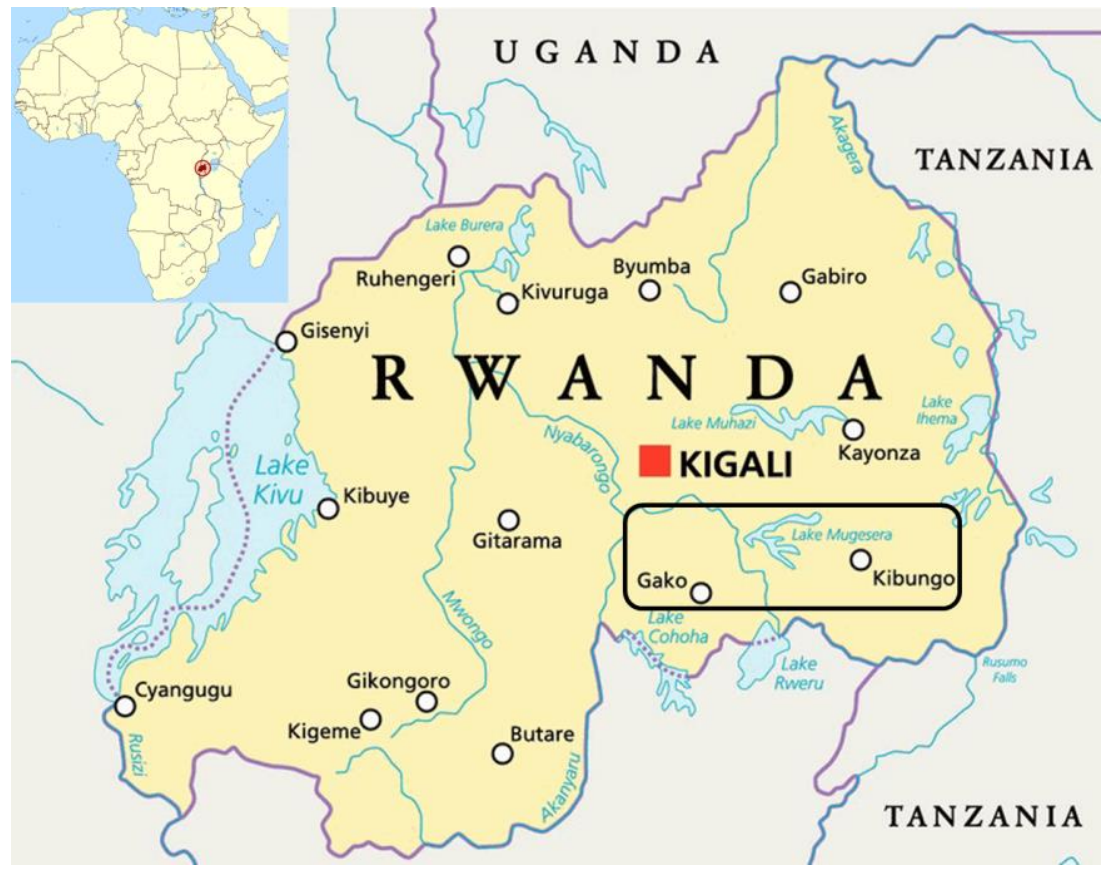

Figure 1 - Location of the study region - Surveyed villages are inside the black rectangle Source of the maps: (Africa Guide, 2019) (Mapsland, 2019) 


\subsection{Data collection}

In October 2017, a survey was performed in the 8 villages in collaboration with the microgrid company which is operating in these villages. 40 households were surveyed in each village -20 electricity customers and 20 who are not customers. The households surveyed were selected quasi-randomly and the respondents were surveyed in-person by the enumerators. There are different sampling probabilities across households due to the fact that the number of households varies from one village to another as well as the share of the households which have access to electricity. We assign a weight to each surveyed household which is equal to the inverse of the probability that the household has of being sampled. The weight therefore corresponds to the number of households represented by this surveyed household. The survey asks the respondent about demographic and economic information and about current water access. In addition, the survey asks the respondent about his/her mWTP for improved domestic water supply, i.e., the maximum price the respondent is willing to pay per unit of water for domestic use. The respondent is also asked about his mWTP for irrigation and these mWTP questions are provided in appendix. The survey responses are also of interest to our partner microgrid electricity provider, who is considering installation of motorized water pumps in the surveyed villages. Only people who planted crops in the last 12 months (approximately $80 \%$ of surveyed households) were asked the question about the mWTP for irrigation, as responses from people who did not plant crops may be less reliable. All respondents agreed to answer the relevant mWTP questions.

The contingent valuation questions for domestic water supply and irrigation were open-ended elicitation questions (see appendix), to allow respondents to relate to the question and minimize information bias. The question on the mWTP for irrigation water does not mention motorized pumping systems explicitly in order to incite people to identify the true service they would receive, which is continuous irrigation. In practice, providing continuous irrigation water in the targeted villages would require motorized pumping because in these villages water sources are too far from the field to perform manual irrigation, irrigation by gravity is not achievable, and trucked water is not used in the region. Finally, irrigation from motorized pumping may take the form of one or several motor-pumps for several fields and we did not want to complicate the question by asking about a specific architecture of the pumping system.

Our mWTP questions ask for the maximum price a respondent would pay per unit of water, as in (Calkins et al. 2002), (Wright et al. 2014) and (Harun et al. 2015). We proposed several units that are commonly used to measure water consumption in the study area (see appendix). We then converted the answers to RWF/L and then to USD/L. Therefore, we interpret the results as the mWTP for a unit of water. It was not possible to get reliable estimates of the intended water quantity consumed because the respondents had not experienced water use with the proposed improved water supply infrastructure. As we do not know the intended quantity consumed, we do not calculate the magnitude of expected total household expenses for improved domestic water and for irrigation, or the total economic surplus generated from these purchases. In this study, the determinants that we consider for the mWTP (section 4.2 and 4.3) are expected to also apply to the expected total household expenses for improved domestic water and for irrigation. In any case, information on the mWTP can inform allocation decisions across multiple types of improved water supplies. In addition, expressing the mWTP per unit of water allows us to compare the domestic and irrigation uses.

We decided not to do a bidding game or choice experiment, which are common methods for contingent valuation, for two reasons. Firstly, we had doubts about the cultural acceptability of such games that mimic negotiation in the targeted communities. These games could have resulted in a reduced response rate, and a degradation of our partner electricity provider's reputation amongst their customers. Also, Hanley et al. (2010) pointed out that choice experiments have trade-offs in areas of low education and where people are not used to choosing among policy options, which is the case in the studied villages. Secondly, the aim of the study is to identify the determinants of the mWTP and not the absolute value of the mWTP. While the hypothetical bias associated with the use of open-ended questions may affect the absolute value of the mWTP, it should not correlate with the determinants that we investigate.

\subsection{Regression model design}

In order to identify the determinants of the mWTP for improved domestic water supply and irrigation, we estimate a model of stated mWTP on household characteristics. It is important to keep in mind that data on mWTP and household characteristics are measured through the survey. In order to account for the different sampling probabilities (section 3.2), we use probability weights in the regression. 
In order to consider zero mWTP values, we use the following tobit model (Tobin, 1958), as in (Wondimu and Bekele, 2011) (Mesa-Jurado et al., 2012) (Cho et al., 2005):

$$
\begin{gathered}
m W T P_{i}^{u *}=\beta_{0}^{u}+\sum_{m=1}^{M^{u}} \beta_{m}^{u} V_{m, i}^{u}+\gamma_{v}^{u}+\epsilon_{i}^{u} \\
m W T P_{i}^{u}=\max \left\{0, m W T P_{i}^{u *}\right\}
\end{gathered}
$$

where $m W T P_{i}^{u}$ is the stated mWTP of household $i$ for use $u(u=\{$ domestic, irrigation $\}), m W T P_{i}^{u *}$ is the corresponding latent value, $V_{m, i}^{u}$ are the values for household $i$ of the explanatory variables considered in the model for use $u, M^{u}$ is the number of explanatory variables in the model for use $u$, the $\beta$ terms are the regression coefficients, $\gamma_{v}^{u}$ is a village fixed effect and $\epsilon_{i}^{u}$ is an error term with mean zero assumed uncorrelated with other explanatory variables. The village fixed effect is included to control for time-invariant unobserved features of villages that may correlate with the mWTP. The model is estimated using maximum likelihood estimation and assuming that $\epsilon_{i}^{u}$ is normally distributed.

The literature review (section 2) is used to choose the variables of our model.

The following demographic variables are included for domestic water and irrigation: education, gender, age, and household size. For domestic water, the number of visits to the health clinic is also included as it is related to the prevalence of water-borne diseases.

Regarding economic variables, the household income in the past 30 days is used as a proxy for household income, for both the domestic water and irrigation models. Indeed, it would have been difficult for respondents to accurately know their income in a larger period of time (e.g., a year). However, we acknowledge that household income is subject to measurement error: monthly income changes with crop cycles during the year and many households rely heavily on household production of food. The village fixed effect in our model allows us to control for the fact that the interviews occurred over some time, and that some villages may have been surveyed before/after harvest. We include business ownership as a proxy for involvement in off-farm activities. We also include an indicator for if a household is an electricity customer. Access to credit is not represented, as few households have access to credit in these villages. For the irrigation model, the proportion of income from agriculture, land ownership and the crop area planted are introduced to represent the economic variables related to agriculture. The distance from the household to the nearest market is not included because a national village concentration policy (Note 2) has encouraged the formation of a market in most villages and the gathering of households inside villages.

For variables related to water access, we include the time to the current water source, the quantity of water consumed, and the satisfaction with current water quantity and quality in the domestic water model. For irrigation, as manual and motorized irrigation are scarce, there is very little variation in current irrigation water access. Therefore, we do not include water access variables in the irrigation mWTP model.

A potential concern is the correlation between the explanatory variables. In order to address this, we performed a multicollinearity analysis. For each water use (domestic, irrigation), we computed the correlation matrix between the variables and the variance inflation factors for the variables. Results (not reported here) show that the explanatory variables in the domestic water model and in the irrigation model are not highly correlated, meaning that coefficients can be separately identified through model estimation.

\section{Results}

\subsection{Summary statistics}

Summary statistics are provided in Table 2 for all households, which is the sample used for the model on domestic water, and for farming households only, which is the sample used for the irrigation model. Only variables used in the models are included. 
Mean

(standard deviation)

\begin{tabular}{|c|c|c|c|c|}
\hline Variable & $\begin{array}{l}\text { Binary/ } \\
\text { Continuous }\end{array}$ & Description & $\begin{array}{l}\text { all } \\
\text { households: } \\
\text { sample for domestic } \\
\text { water model }\end{array}$ & $\begin{array}{l}\text { farming } \\
\text { households: } \\
\text { sample for irrigation } \\
\text { model }\end{array}$ \\
\hline \multicolumn{5}{|l|}{ Demographic } \\
\hline Education & Binary & $\begin{array}{l}\text { Primary education completed by the } \\
\text { respondent ( } 1 \text { if yes) }\end{array}$ & $\begin{array}{l}0.073 \\
(0.26)\end{array}$ & $\begin{array}{l}0.088 \\
(0.28)\end{array}$ \\
\hline Gender & Binary & Gender of the respondent ( 1 if male) & $\begin{array}{c}0.53 \\
(0.50)\end{array}$ & $\begin{array}{c}0.54 \\
(0.50)\end{array}$ \\
\hline Age & Continuous & Age of the respondent (years) & $\begin{array}{c}40 \\
(14)\end{array}$ & $\begin{array}{c}40 \\
(14)\end{array}$ \\
\hline $\begin{array}{l}\text { Proportion of } \\
\text { children }\end{array}$ & Continuous & $\begin{array}{l}\text { Proportion of children } \\
\text { ( }<12 \text { years old) per household }\end{array}$ & $\begin{array}{c}0.35 \\
(0.23)\end{array}$ & $\begin{array}{c}0.37 \\
(0.22)\end{array}$ \\
\hline Household size & Continuous & Number of people per household & $\begin{array}{l}4.5 \\
(2.3)\end{array}$ & $\begin{array}{l}4.8 \\
(2.5)\end{array}$ \\
\hline $\begin{array}{l}\text { Visits to health } \\
\text { clinic }\end{array}$ & Continuous & $\begin{array}{l}\text { Average number of visits to the } \\
\text { health clinic per capita per month }\end{array}$ & $\begin{array}{c}0.42 \\
(0.46)\end{array}$ & - \\
\hline \multicolumn{5}{|l|}{ Economic } \\
\hline Income & Continuous & $\begin{array}{l}\text { Household income in the past } \\
30 \text { days (USD)* }\end{array}$ & $\begin{array}{c}50 \\
(76)\end{array}$ & $\begin{array}{c}56 \\
(86)\end{array}$ \\
\hline Business owner & Binary & $\begin{array}{l}\text { At least one member of the } \\
\text { household runs a business ( } 1 \text { if yes) }\end{array}$ & $\begin{array}{c}0.26 \\
(0.43)\end{array}$ & $\begin{array}{c}0.27 \\
(0.45)\end{array}$ \\
\hline Electricity customer & Binary & $\begin{array}{l}\text { The household is connected to the } \\
\text { electricity service ( } 1 \text { if yes) }\end{array}$ & $\begin{array}{c}0.19 \\
(0.39)\end{array}$ & $\begin{array}{c}0.22 \\
(0.42)\end{array}$ \\
\hline $\begin{array}{l}\text { Proportion of } \\
\text { income from } \\
\text { agriculture }\end{array}$ & Continuous & $\begin{array}{l}\text { Proportion of household income that } \\
\text { comes from selling agricultural } \\
\text { products }\end{array}$ & - & $\begin{array}{c}0.27 \\
(0.37)\end{array}$ \\
\hline Land owned & Binary & $\begin{array}{l}\text { Household members own the } \\
\text { agricultural land they work on } \\
\text { (1 if yes) }\end{array}$ & - & $\begin{array}{c}0.70 \\
(0.46)\end{array}$ \\
\hline Area planted & Continuous & $\begin{array}{l}\text { Crop area planted within the past } 12 \\
\text { months (ha) }\end{array}$ & - & $\begin{array}{c}0.72 \\
(1.13)\end{array}$ \\
\hline \multicolumn{5}{|l|}{ Water access } \\
\hline $\begin{array}{l}\text { Proportion of } \\
\text { expenses dedicated } \\
\text { to domestic water }\end{array}$ & Continuous & $\begin{array}{l}\text { Proportion of expenses dedicated to } \\
\text { domestic water }\end{array}$ & $\begin{array}{c}0.031 \\
(0.052)\end{array}$ & - \\
\hline $\begin{array}{l}\text { Water collection } \\
\text { time }\end{array}$ & Continuous & $\begin{array}{l}\text { Average time to collect water daily } \\
\text { per person collecting water (min) }\end{array}$ & $\begin{array}{c}40 \\
(31)\end{array}$ & - \\
\hline Water consumption & Continuous & $\begin{array}{l}\text { Average daily domestic water } \\
\text { consumption per capita }(\mathrm{L})\end{array}$ & $\begin{array}{c}16 \\
(19)\end{array}$ & - \\
\hline $\begin{array}{l}\text { Water quality } \\
\text { satisfaction }\end{array}$ & Binary & $\begin{array}{l}\text { Satisfaction of the respondent about } \\
\text { domestic water quality ( } 1 \text { if yes) }\end{array}$ & $\begin{array}{c}0.38 \\
(0.49)\end{array}$ & - \\
\hline $\begin{array}{l}\text { Water quantity } \\
\text { satisfaction }\end{array}$ & Binary & $\begin{array}{l}\text { Satisfaction of the respondent about } \\
\text { domestic water quantity ( } 1 \text { if yes) }\end{array}$ & $\begin{array}{c}0.79 \\
(0.42)\end{array}$ & - \\
\hline \multicolumn{5}{|l|}{ Willingness to pay } \\
\hline mWTP domestic & Continuous & $\begin{array}{l}\text { mWTP for improved domestic water } \\
\text { supply (USD/L)* }\end{array}$ & $\begin{array}{c}0.0014 \\
(0.0013)\end{array}$ & - \\
\hline mWTP irrigation & Continuous & mWTP for irrigation (USD/L)* & - & $\begin{array}{c}0.00038 \\
(0.00086) \\
\end{array}$ \\
\hline \multicolumn{3}{|c|}{ Sample size ${ }^{* *}$} & 316 & 248 \\
\hline
\end{tabular}

Note. Average not in parentheses; Standard deviation in parentheses.

*Exchange rate: $855 \mathrm{RWF} / \mathrm{USD}$.

**Households included in the samples are the ones that answered all the questions related to the variables. 
The summary statistics on demographic variables indicate that only $7 \%$ of the respondents have completed primary school and that $35 \%$ of the households' population is composed of children aged below 12 . The demographic variables means are similar between all households and farming households only. Data indicate that people visit a health clinic approximately every 2 months. The majority of the households live below the international poverty line (1.9 USD per person per day). In addition, the mean crop area planted is lower than 1 ha and farming products are mostly used for household consumption. This may explain why a large share of farming households $(27 \%)$ also run a non-farm business to supplement farming income. The majority of households own the land they work on. Regarding domestic water access, water purchases represent a small share of household expenses. The quantity of water consumed per capita per day is restricted, especially given that water consumption is split between human consumption, cooking, and hygiene. Consumption may be suppressed by the significant time and effort required for water collection (typically 40 minutes per person per day) including walking and queuing at water collection points. However, the level of satisfaction reveals that water quality is perceived as a much bigger problem by the surveyees than water quantity.

The average mWTP for improved domestic water is 3.5 times as high as for irrigation. Moreover, the coefficient of deviation (ratio of the standard deviation to the mean) for the mWTP for irrigation is 2.5 times as high as for domestic water. It means that the mWTP responses for irrigation are more variable than the responses for domestic water. However, these differences in mean and deviation of mWTP have to be interpreted with caution because the mWTP questions were not phrased exactly the same way for domestic water and irrigation. As explained previously, these different phrasings are due to the fact that the study mainly focuses on the determinants of mWTP and not on its absolute value.

\subsection{Determinants of the $\mathrm{mWTP}$ for improved domestic water supply}

The results of the regression describing the mWTP for improved domestic water are presented in Table 3. Weighted results are presented with and without village fixed effects.

Results indicate that the main demographic determinant of the mWTP for domestic water is the proportion of children in the household. The higher the proportion of children, the lower the mWTP. This could be because children often participate in the collection of water for domestic use, making it easier to collect more water. More children may also allow households to collect more firewood to boil low quality water and combat water borne diseases. Results also provide suggestive evidence that the age of the respondent is negatively correlated with the mWTP, which is similar to several studies in the literature. Possible explanations include that older people have a shorter planning horizon, inertia related to age and that relatives often fetch water for old people in the considered villages. The business owner variable is positively correlated with the mWTP for domestic water access. This could occur if business owners have a better appreciation of the benefits of improved domestic water access. The electricity customer variable is not correlated with the mWTP. The satisfaction with water quality and quantity are both strongly negatively correlated with the mWTP, which is consistent with the literature. Indeed, it is logical that households which are not satisfied with the low quality of their water source compared to existing alternatives have a higher mWTP. There is suggestive evidence that the water collection time is negatively correlated with the mWTP. This could occur if households that currently travel further have lower shadow values of time. Thus the savings from closer water would be less valuable. It could also occur if larger travel distances take people to better quality water sources. In this case, a new source with less certain quality may have lower value.

We extend the analysis regarding the influence of electricity access on the mWTP for water infrastructure by exploring electricity service satisfaction. More specifically, for the 160 households of the dataset which are electricity customers, we study the relation between their satisfaction with the electricity service and their mWTP for improved domestic water. The satisfaction with the electricity service is proxied by the reliability of the service. Data about interruptions in the electricity service for each electricity customer were collected through the survey. The electricity service reliability variable is equal to 1 if there was no interruption in the electricity service during the week preceding the survey and to 0 if there was. For the 160 households which are electricity customers, the mWTP for improved domestic water is regressed against the electricity service reliability variable, using the tobit model with weighted data. Moreover, the same regression is also performed by including the other control variables of the model (those from Table 3). There is no correlation between the satisfaction with the electricity service and the mWTP for improved domestic water supply. This may be because electricity supply and water supply are viewed as two very different types of services by the respondents. Alternatively, poor households such as the ones in the surveyed villages, may not be demanding in terms of the quality of services provided (Deloitte, 2016). 


\begin{tabular}{lcr}
\hline Variable & $\begin{array}{c}\text { Without } \\
\text { Village Fixed Effect }\end{array}$ & $\begin{array}{c}\text { With } \\
\text { Village Fixed Effer }\end{array}$ \\
Demographic & & -0.000389 \\
Education & & $(0.000254)$ \\
& -0.000240 & 0.000159 \\
Gender & $(0.000296)$ & $(0.000166)$ \\
& 0.000180 & $-1.57 \mathrm{e}-05^{* *}$ \\
Age & $(0.000189)$ & $(7.81 \mathrm{e}-06)$ \\
& $-1.26 \mathrm{e}-05$ & $-0.000688^{* *}$ \\
Proportion of children & $(7.83 \mathrm{e}-06)$ & $(0.000325)$ \\
& $-0.000841 *$ & $-4.42 \mathrm{e}-06$ \\
Household size & $(0.000432)$ & $(3.21 \mathrm{e}-05)$ \\
Visits to health clinic & $-3.26 \mathrm{e}-05$ & -0.000310 \\
& $(3.25 \mathrm{e}-05)$ & $(0.000213)$
\end{tabular}

\section{Economic}

Income

Business owner

Electricity customer

$\begin{array}{cc}(0.000210) & (0.000181) \\ 0.000246 & 0.000208 \\ (0.000176) & (0.000145)\end{array}$

\section{Water access}

Proportion of expenses dedicated to domestic water

Water collection time

Water consumption

Water quality satisfaction

Note. Output of tobit model. The dependent variable is left-censored at 0 . Note. Regression coefficients estimates not in parentheses. Standard errors in parentheses. $* * * \mathrm{p}<0.01, * * \mathrm{p}<0.05, * \mathrm{p}<0.1$

\subsection{Determinants of the $m W T P$ for irrigation}

The results of the regression describing the mWTP for irrigation are presented in Table 4 . Weighted results are presented with and without village fixed effects.

There is a positive correlation between education and the mWTP for irrigation water, which is consistent with the literature. Indeed, educated famers may be more aware that irrigation can improve productivity. There is suggestive evidence that the age of the respondent is negatively correlated with the mWTP. This may be due to the fact that older respondents have a shorter planning horizon and to inertia related to age. Further, business ownership is positively correlated with the mWTP for irrigation water for all specifications. This could occur if 
business owners process their own agricultural output to sell, if business owners have a better appreciation of the benefits of irrigation, and/or if they have better market access where they could sell increases in production. As for domestic water, the electricity customer variable is not correlated with the mWTP for irrigation. The crop area planted is positively correlated with the mWTP. This result was expected based on the existing literature and because farmers with more land see a bigger impact from yield increases.

As with domestic water, the regression between the presence of interruptions in the electricity service and the mWTP for irrigation water is performed for the 137 households which planted land in the last 12 months and are connected to electricity, using the tobit model. In this case as well, there is no correlation between the satisfaction with the electricity service and the mWTP for irrigation.

Table 4 - Determinants of the mWTP for irrigation - Weighted results

\begin{tabular}{lcc}
\hline Variable & Without & With \\
& Village Fixed Effect & Village Fixed Effect \\
\hline
\end{tabular}

\section{Demographic}

Education

Gender

Age

Proportion of children

Household size

$\begin{array}{cc}0.000944 * * & 0.00104^{* *} \\ (0.000414) & (0.000482) \\ 5.62 \mathrm{e}-05 & -0.000352 \\ (0.000367) & (0.000350) \\ -2.57 \mathrm{e}-05 & -3.21 \mathrm{e}-05^{* *} \\ (1.70 \mathrm{e}-05) & (1.54 \mathrm{e}-05) \\ 0.000582 & 0.000809 \\ (0.00103) & (0.00102) \\ 1.77 \mathrm{e}-05 & -3.37 \mathrm{e}-06 \\ (4.33 \mathrm{e}-05) & (4.29 \mathrm{e}-05)\end{array}$

Economic

Income

$-3.94 \mathrm{e}-06$

$-1.96 \mathrm{e}-06$

(2.57e-06)

$0.000846^{* * *}$

(2.42e-06)

Business owner

(0.000326)

0.000770 **

(0.000336)

$-0.000508$

$-0.000324$

(0.000319)

(0.000307)

0.000180

0.000343

(0.000576)

$(0.000461)$

$-0.000288$

$-0.000361$

(0.000390)

(0.000376)

$0.000429 * *$

(0.000202)

$0.000332 *$

(0.000177)

$-0.000482$

$-0.000599$

(0.00102)

Sample size

248

248

Note. Output of tobit model. The dependent variable is left-censored at 0.

Note. Regression coefficients estimates not in parentheses. Standard errors in parentheses.

$* * * \mathrm{p}<0.01, * * \mathrm{p}<0.05, * \mathrm{p}<0.1$

\section{Discussion, conclusion and policy implications}

Results indicate that the determinants ( $\mathrm{p}<0.1$ for all model specifications) of the mWTP for improved domestic water are the proportion of children in the household, business ownership, and satisfaction with water quantity and quality. The determinants $(\mathrm{p}<0.1$ for all model specifications) of the mWTP for irrigation are respondents' education, business ownership and crop area planted. Importantly, the majority of the determinants of the mWTP for domestic water and irrigation are different, which suggests that it may be difficult to design policy schemes that target both water uses at the same time. The only determinant that is common to domestic 
water and irrigation is business ownership. Consequently, if a scheme which targets both uses is to be implemented, business owners could be priority customers. Regarding domestic water, given that the dissatisfaction about water quality is one of the main mWTP drivers, an effective policy may be to target areas where the quality of existing water sources is very poor. This is notably the case of surface sources like lakes and rivers. For irrigation, crop area planted is one of the main determinants, and companies, NGOs, or governments may therefore want to propose irrigation to farmers who work on large fields. However, this might contribute to increasing inequalities amongst farmers.

This study also shows that the mWTP for domestic water and irrigation are not strongly influenced by the fact that households are connected to electricity, which is provided by solar microgrids in our case, or by the satisfaction with the microgrid electricity company. Microgrid companies may therefore be equally interested in targeting current customers and non-customers when it comes to providing water-related services.

Finally, results indicate that the average mWTP for domestic water is higher than for irrigation and that the mWTP dispersion is lower for domestic water than for irrigation. Investments in domestic water may therefore appear safer. However, microgrid companies may still also want to target irrigation water as it could generate cash through crop sales that could be used for buying electricity. In addition, the initial investment per unit of water provided may be lower for pumping systems for irrigation than for domestic water. Indeed, domestic water systems often require drilling for accessing drinkable underground water and building water towers, which are two costly operations (Harvey and Reed 2004; Meunier et al. 2018). Finally, while the mWTP is higher for domestic uses, agriculture may use higher volumes of water. Therefore, with a low marginal cost system, the return to investment could be higher for irrigation systems.

The main limitations of our study are the ones associated with stated preferences methods (Hausman 2012). The use of stated preferences is justified by the fact that revealed preferences methods are not applicable in this case. Another limitation is the use of open-ended questions and the associated potential hypothetical bias. The motivation for this choice is that bidding games and choice experiments may not be culturally accepted in the targeted communities. They may therefore result to a lower response rate and be detrimental to the reputation of the microgrid company with which the study is performed. Also, this study focuses on the determinants of the mWTP, and there is no reason to think that the hypothetical bias will affect these determinants.

Future work should first quantify mWTP and expected total household expenses for alternative types of water infrastructure. In addition, future work could examine sources of heterogeneity in the determinants of mWTP. This would facilitate the extrapolation of results to other rural areas of developing countries.

Despite these limitations, the results of this study can help companies, governments and NGOs to compare the benefits and revenue generated by infrastructure for domestic water, irrigation, and other services. It can also provide useful information for the deployment of improved water infrastructure, notably in villages which are partially electrified, which is the case of an increasing number of villages in developing regions. Finally, it is expected that our partner electricity provider will install motorized water pumps in some of the studied villages in the next years. It will therefore be possible to compare the outcomes of our stated preference study to revealed preference results. This will build on the knowledge of stated preferences methods, which are often required when the demand for a service has not yet been fulfilled.

\section{Notes}

1. 9 villages were in fact surveyed but one is not considered due to its relatively large size and lack of representativeness for typical rural villages.

2. The 'villagisation' policy (umudugudu) started in 1994, after the genocide, to settle returnees. Households were grouped into dense villages.

\section{Acknowledgments}

We would like to thank the surveyors for their high quality work and the surveyees for answering our questions. Finally, we would like to thank our partner electricity provider, the company MeshPower, for collaborating on this research. We would like to thank the anonymous reviewers and the editor for their comments and suggestions which allowed us to improve the article. 


\section{Data availability statement}

An anonymized version of the survey variables used in this analysis can be made available upon request.

\section{Disclosure statement}

No potential conflict of interest was reported by the authors.

\section{Funding}

This work is supported by a public grant overseen by the French National research Agency (ANR) as part of the "Investissement d'Avenir" program, through the "IDI 2015" project funded by the IDEX Paris-Saclay, ANR-11IDEX0003-02.

\section{References}

Adenike AA, Titus OB. 2009. Determinants of willingness to pay for improved water supply in Osogbo Metropolis; Osun State, Nigeria. Research Journal of Social Sciences. 4: 1-6.

Africa Guide. 2019. Rwanda Guide; [accessed 2019 May 21]. https://www.africaguide.com/country/rwanda/

Akram AA, Olmstead SM. 2011. The value of household water service quality in Lahore, Pakistan. Environmental and Resource Economics. 49(2): 173-198.

Akter S. 2007. Farmers' willingness to pay for irrigation water under government managed small scale irrigation projects in Bangladesh. Journal of Bangladesh Studies. 9: 21-31.

Al-Assaf AA. 2015. Applying contingent valuation to measure the economic value of forest services: a case study in Northern Jordan. International Journal of Sustainable Development \& World Ecology. 22(3): $242-250$.

Alhassan M, Loomis J, Frasier M, Davies S, Andales A. 2013. Estimating farmers' willingness to pay for improved irrigation: an economic study of the Bontanga irrigation scheme in Northern Ghana. Journal of Agricultural Science. 5(4): 31-42.

Alhassan M, Mohammed J. 2013. Households' demand for better solid waste disposal services: case study of four communities in the New Juaben municipality, Ghana. Journal of Sustainable Development. 6(11): $16-25$.

Altaf A, Jamal H, Whittington D. 1992. Willingness to pay for water in rural Punjab, Pakistan. Washington (USA): World Bank.

Angella N, Dick S, Bagamba F. 2014. Willingness to pay for irrigation water and its determinants among rice farmers at Doho Rice Irrigation Scheme (DRIS) in Uganda. Journal of Development and Agricultural Economics. 6(8): 345-355.

Arouna A, Dabbert S. 2012. Estimating rural households' willingness to pay for water supply improvements: a Benin case study using a semi-nonparametric bivariate probit approach. Water International. 37(3): 293-304.

Bartram J, Cairncross S. 2010. Hygiene, sanitation, and water: forgotten foundations of health. PLoS Medicine, 7(11): e1000367.

Bbox. 2018. United Kingdom: Bbox; [accessed 2018 Dec 20]. http://www.bboxx.co.uk/.

Bennett J, Birol E. 2010. Choice experiments in developing countries: implementation, challenges and policy implications. Cheltenham (UK): Edward Elgar.

Bhattarai K. 2015. Households' willingness to pay for improved solid waste management in Banepa municipality, Nepal. Environment and Natural Resources Journal. 13(2): 14-25.

Boadu FO. 1992. Contingent valuation for household water in rural Ghana. Journal of Agricultural Economics. 43(3): 458-465.

Calkins P, Larue B, Vézina M. 2002. Willingness to pay for drinking water in the sahara: the case of Douentza in Mali. Cahiers D'économie et Sociologie Rurales. 64: 37-56.

Campana PE, Li H, Yan J. 2013. Dynamic modelling of a PV pumping system with special consideration on water demand. Applied Energy. 112: 635-645. 
Cho Y, Easter KW, McCann LM, Homans F. 2005. Are rural residents willing to pay enough to improve drinking water quality? Journal of the American Water Resources Association. 41(3): 729-740.

Davies H. 2017. Futurepump is now in Rwanda! Rwanda: Futurepump; [accessed 2018 Dec 19]. https://futurepump.com/futurepump-rwanda/

Deloitte. 2016. Customer Service Incentives: statistical exploration of the water industry SIM. London (UK): Deloitte.

Ezebilo EE, Mattsson L, Afolami CA. 2010. Economic value of ecotourism to local communities in the Nigerian rainforest zone. Journal of Sustainable Development. 3(1): 51-60.

Farolfi S, Mabugu RE, Ntshingila SN. 2007. Domestic water use and values in Swaziland: a contingent valuation analysis. Agrekon. 46(1): 157-170.

Fujita Y, Fujii A, Furukawa S, Ogawa T. 2005. Estimation of willingness-to-pay (WTP) for water and sanitation services through contingent valuation method (CVM): A case study in Iquitos City, The Republic of Peru. JBICI Review. 11: 59-87.

Gaia Survey Rwanda. 2018. Gaia Survey Rwanda - about us. Rwanda: Gaia Survey; [accessed 2018 Dec 19]. http://www.gaiasurveyrwanda.com/about/.

Graham JP, Hirai M, Kim SS. 2016. An analysis of water collection labor among women and children in 24 subSaharan African countries. PloS One. 11(6): e0155981.

Hanley N, Mourato S, Wright RE. 2010. Choice modelling approaches: A superior alternative for environmental valuation. Journal of Economic Surveys. 15(3): 435-462.

Harun R, Muresan IC, Arion FH, Dumitras DE, Lile R. 2015. Analysis of factors that influence the willingness to pay for irrigation water in the Kurdistan Regional government, Iraq. Sustainability. 7(7): 9574-9586.

Harvey PA, Reed RA. 2004. Rural water supply in Africa: building blocks for handpump sustainability. Loughborough (UK): WEDC, Loughborough University.

Hausman J. 2012. Contingent valuation: from dubious to hopeless. Journal of Economic Perspectives. 26(4): 4356.

Howard G, Bartram J. 2003. Domestic water quantity, service level, and health. Geneva (CH): World Health Organization.

Kaffashi S, Shamsudin MN, Radam A, Rahim KA, Yacob MR. 2013. We are willing to pay to support wetland conservation: local users' perspective. International Journal of Sustainable Development \& World Ecology. 20(4): 325-335.

Kaldellis JK, Spyropoulos GC, Kavadias KA, Koronaki IP. 2009. Experimental validation of autonomous PVbased water pumping system optimum sizing. Renewable Energy. 34(4): 1106-1113.

Kaliba ARM, Norman DW, Chang YM. 2003. Willingness to pay to improve domestic water supply in rural areas of Central Tanzania: Implications for policy. International Journal of Sustainable Development \& World Ecology. 10(2): 119-132.

Kiprop J, Mulungu K, Kibet N, Macharia A. 2017. Determinants of smallholder farmers' willingness to pay for irrigation water in Kerio Valley basin, Kenya. Journal of Sustainable Development. 10(2): 135-142.

Manning DT, Loomis JB. 2016. Consumer preferences for fixed versus variable quantities of electricity: joint estimation of contingent quantity and valuation methods. Environment and Development Economics. 21(6): 789-811.

Manning DT, Means P, Zimmerle D, Galvin K, Loomis J, Paustian K. 2015. Using contingent behavior analysis to measure benefits from rural electrification in developing countries: an example from Rwanda. Energy Policy. 86: 393-401.

Mapsland. 2019. Detailed location map of Rwanda in Africa; [accessed 2019 May 21]. https://www.mapsland.com/africa/rwanda/detailed-location-map-of-rwanda-in-africa

Mesa-Jurado MA, Martin-Ortega J, Ruto E, Berbel J. 2012. The economic value of guaranteed water supply for irrigation under scarcity conditions. Agricultural Water Management. 113: 10-18.

Meshpower. 2018. Rwanda: Meshpower; [accessed 2018 Dec 20]. http://www.meshpower.co.rw/ 
Meunier S, Heinrich M, Quéval L, Cherni JA, Vido L, Darga A, Dessante P, Multon B, Kitanidis PK, Marchand C. 2019. A validated model of a photovoltaic water pumping system for off-grid rural communities. Applied Energy. 241: 580-591.

Meunier S, Queval L, Darga A, Dessante P, Marchand C, Heinrich M, Cherni J, Vido L, Multon B. 2018. Influence of the temporal resolution of the water consumption profile on photovoltaic water pumping systems modelling and sizing. Proceedings of the 7th International Conference on Renewable Energy Research and Applications (ICRERA); Oct 14-17; Paris, France. IEEE. p. 494-499.

Mezgebo A, Tessema W, Asfaw Z. 2013. Economic values of irrigation water in Wondo Genet District, Ethiopia: An application of contingent valuation method. Journal of Economics and Sustainable Development. 4(2): 23-36.

Ngabonziza P, Maimbo MM. 2010. Rwanda irrigation master plan. Rwanda: The Government of Rwanda, Ministry of Agriculture \& Animal Resources, Ebony Enterprises Limited, The World Agroforestry Centre (ICRAF).

Ngoga TH. 2015. Rwanda rural settlement - An assessment of land management and livelihoods. London (UK): International Alert.

Perez-Pineda F, Quintanilla-Armijo C. 2013. Estimating willingness-to-pay and financial feasibility in small water projects in El Salvador. Journal of Business Research. 66(10): 1750-1758.

Popoola L, Ajewole O. 2002. Willingness to pay for rehabilitation of Ibadan urban environment through reforestation projects. International Journal of Sustainable Development \& World Ecology. 9(3): 256268.

Rahman MM, Alam K, Karim R, Islam MK. 2017. Willingness to pay for improved water supply: a policy implications for future water security. American Journal of Environmental and Resource Economics. 2(4): 116-122.

Rwandan Ministry of Infrastructure. 2017. Rwanda overview: water, sanitation and hygiene. Rwanda: Rwandan Ministry of Infrastructure

Tobin J. 1958. Estimation of relationships for limited dependent variables. Econometrica. 26(1): 24-36.

[UN] United Nations. 2015. The millennium development goals report. New York (NY): United Nations.

[UN] United Nations. 2018. Goal 6: Ensure access to water and sanitation for all. New York (NY): United Nations; [accessed 2018 Dec 5]. https://www.un.org/sustainabledevelopment/water-and-sanitation/

Whittington D, Briscoe J, Mu X, Barron W. 1990. Estimating the willingness to pay for water services in developing countries: A case study of the use of contingent valuation surveys in southern Haiti. Economic Development and Cultural Change. 38(2): 293-311.

Whittington D, Lauria DT, Mu X. 1991. A study of water vending and willingness to pay for water in Onitsha, Nigeria. World Development. 19(2-3): 179-198.

Wondimu S, Bekele W. 2011. Determinants of individual willingness to pay for quality water supply: the case of Wonji Shoa Sugar Estate, Ethiopia. Proceedings of $1^{\text {st }}$ International Conference on Water and Society; Dec 5-7; Las Vega (NV). p. 59-70.

World Bank. 1993. The demand for water in rural areas: determinants and policy implications. The World Bank Research Observer. 8(1): 47-70.

World Health Organization, United Nations Children's Fund. 2010. Progress on sanitation and drinking water. Geneva $(\mathrm{CH})$ : World Health Organization.

Wright SG, Muralidharan D, Mayer AS, Breffle WS. 2014. Willingness to pay for improved water supplies in rural Ugandan villages. Journal of Water, Sanitation and Hygiene for Development. 4(3): 490-498.

Yami M. 2016. Irrigation projects in Ethiopia: what can be done to enhance effectiveness under "challenging contexts"? International Journal of Sustainable Development \& World Ecology. 23(2): 132-142.

You L, Ringler C, Wood-Sichra U, Robertson R, Wood S, Zhu T, Nelson G, Guo Z, Sun Y. 2011. What is the irrigation potential for Africa? A combined biophysical and socioeconomic approach. Food Policy. 36(6): 770-782. 
Zakaria H, Abujaja AM, Adam H, Nabila AY, Mohammed I. 2013. Factors affecting farmers willingness to pay for improved irrigation service: A case study of Bontanga Irrigation Scheme in Northern Ghana. International Journal of Agricultural Economics and Extension. 2(1): 68-76.

\section{Appendix: Contingent valuation survey questions}

\section{Domestic water}

Would you agree to pay to be able to use a motorized water pump in your village?

If yes, what is the maximum price you would be willing to pay per jerrycan/bucket/L?

\section{Irrigation}

Would you agree to pay to have enough water to irrigate your land during the whole year?

If yes, what is the maximum price you would be willing to pay per jerrycan/bucket $/ \mathrm{L} / \mathrm{m}^{3}$ ?

\section{Remarks}

If people answered that they are not willing to pay, we considered that their mWTP is $0 \mathrm{RWF} / \mathrm{L}$.

If people gave a mWTP in RWF per bucket or jerrycan, the surveyor asked the respondent to show him a typical bucket or jerrycan used for the considered water use and measured it. The greatest majority of respondents use jerrycans of $20 \mathrm{~L}$.

The answers were then converted to USD/L (Exchange rate: 855 RWF/USD). 